\title{
ANTITHROMBOTIC DRUGS IN CIRRHOSIS
}

\author{
Nicoleta State ${ }^{1,2}$, Victor Stoica ${ }^{1,3}$ \\ ${ }^{1}$ University of Medicine and Pharmacy "Carol Davila", Bucharest \\ ${ }^{2}$ County Emergency Hospital "St. Joan the New", Suceava \\ ${ }^{3}$ The Clinical Hospital "MD Ioan Cantacuzino", Bucharest \\ Corresponding author: \\ Nicoleta State \\ County Emergency Hospital "St. Joan the New", blvd. 1 Decembrie 1918, nr 21 bis, Suceava, \\ county Suceava, Internal Medicine department \\ E-mail: dr.state.nicoleta@gmail.com
}

\begin{abstract}
In patients with liver cirrhosis treated for portal vein thrombosis, there was no increase in the risk of bleeding, but there was a decrease in the incidence of liver decompensation and an increase in the survival of treated patients when compared to the untreated ones ${ }^{(1)}$.

Current guidelines ${ }^{(2)}$ do not provide specific recommendations for the prophylaxis or treatment of thromboembolic diseases in patients with liver cirrhosis ${ }^{(3)}$.

In order to determine the influence of anti-thrombotic treatment on the prognosis of liver cirrhosis, 85 patients with liver cirrhosis were followed clinically, by laboratory and ultrasound parameters, for 6 months. Microsoft Excel and IBM SPSS Statistics 20 were used to analyse the data of patients, divided into two groups according to the presence or absence of antithrombotic treatment initiated for cardiovascular pathology.

The obtained results showed that the mortality rate between the two groups was similar: $11.54 \%$ untreated, $12.12 \%$ treated, the decompensation rate of untreated patients was higher than that of the treated ones (36.54\% vs. 24.24\%) with antithrombotic drugs and that no patient among those treated with antithrombotic drugs showed upper digestive haemorrhage ( $p=0.038)$.

The conclusions drawn from this study were that patients with liver cirrhosis in antithrombotic treatment have a better prognosis than untreated ones, in the absence of major bleeding complications, but for a change in guidelines and current practice, studies are needed on a larger number of patients in order to validate these observations.
\end{abstract}

Keywords: liver cirrhosis, antithrombotic drugs, anticoagulation, prognosis. 


\section{INTEH}

\section{Rezumat}

În cazul pacienților cu ciroză hepatică tratați pentru tromboză de venă portă nu s-a raportat creșterea riscului de sângerare, în schimb s-a observat o scădere a incidenței decompensării hepatice și o creștere a supraviețuirii pacienților tratați față de cei netratați(i)

Ghidurile actuale(2) nu oferă recomandări specifice pentru profilaxia sau tratamentul bolilor tromboembolice la pacienții cu ciroză hepatică ${ }^{(3)}$.

În scopul determinării influenţei tratamentului antitrombotic asupra prognosticului cirozei hepatice, 85 de pacienţi cu cirozăa hepatică au fost urmăriți clinic, prin parametri de laborator și ecografici timp de 6 luni. Au fost analizate cu ajutorul Microsoft Excel și IBM SPSS Statistics 20 datele pacienților, împărțiți în două loturi în funcție de prezența sau absența tratamentului antitrombotic inițiat pentru patologie cardiovasculară.

Rezultatele obținute au arătat că rata de mortalitate între cele două loturi a fost asemănătoare: 11,54\% netratați 12,12\% tratați, rata de decompensare a pacienţilor netratați a fost mai mare decât a celor tratați $(36,54 \%$ vs 24,24\%) cu antitrombotice și că niciun pacient din rândul celor tratați cu antitrombotice nu a prezentat hemoragie digestivă superioară $(p=0.038)$.

Concluziile trase în urma acestui studiu au fost că pacienții cu ciroză hepatică în tratament antitrombotic au un prognostic mai bun decât cei netratați, în absența complicațiilor hemoragice majore, însă pentru producerea unei schimbări în ghiduri și în practica curentă sunt necesare studii pe un număr mai mare de pacienți care să valideze aceste observații.

Cuvinte cheie: ciroză hepatică, antitrombotice, anticoagulare, prognostic. 


\section{Introduction}

The theory of "spontaneous anticoagulation" or "natural protection against thrombotic events" of patients with liver cirrhosis is obsolete. However, clinicians still avoid administering antithrombotic drugs to patients with cirrhosis, even in the case of those who have a clear indication for another condition $^{(4)}$.

Some studies have shown not only that cirrhotic patients are not protected from thrombotic risk, but even that it is higher than in the general population ${ }^{(2)}$.

Patients with cirrhosis have a reduction in anticoagulation proteins (antithrombin III, protein S, protein $\mathrm{C}$ ) and an increase in procoagulant factors such as factor VIII. The fibrinolytic system is also conditioned by liver function, plasminogen, antiplasmin, plasmin inhibitor and tissue factor inhibitor being synthesized in the liver. Thrombopoietin, the regulator of platelet production in megakaryocytes, is synthesized by the liver ${ }^{(1)}$. This results in a rearrangement of pro and anticoagulant factors, the balance being tilted toward both bleeding and thrombosis. Although it is difficult to maintain a balance, it can be attained in these patients by achieving "rebalanced homeostasis", but stressful conditions such as infections, encephalopathy or bleeding can unsettle the balance.

In general, patients with liver cirrhosis do not receive antithrombotic drugs unless they have portal vein thrombosis (PVT), venous thromboembolism, or associated pathologies that predispose to thrombotic risk.

Interestingly, increase in the risk of bleeding was not reported in patients treated for portal vein thrombosis. Moreover, there was a decrease in the incidence of liver decompensation and an increase in the survival of treated patients as opposed to untreated ones ${ }^{(1)}$.
In the study of Villa et al. ${ }^{(5)}$ LMWG (low molecular weight heparin) was administered prophylactically and it was also noticed not only that patients receiving antithrombotic treatment had a lower rate of developing PVT, but also that decompensation episodes were less frequent.

Current guidelines ${ }^{(2)}$ do not provide specific recommendations for the prophylaxis or treatment of thromboembolic diseases in patients with liver cirrhosis ${ }^{(3)}$. Most current recommendations are based on extrapolations of data from studies on patients with cirrhosis anti-coagulated for PVT. Given the reluctance to prophylactically administer antithrombotic drugs to patients with cirrhosis, the study of cirrhotic patients who are already being treated with $A D$ (antithrombotic drugs) for other conditions is an alternative to discover the particularities of this therapy in these patients.

\section{Objectives}

The objectives of the present study were to find out if and how antithrombotic treatment influences the evolution of cirrhosis, especially noting the hemorrhagic side effects.

\section{Material and method}

Patients were enrolled from a tertiary hospital, from medical departments, and included in the study were those known to have liver cirrhosis or those whose clinical, biological and imaging data indicated cirrhosis at the time of enrolment.

The patients with neoplasia at the time of enrolment, with severe hepatic encephalopathy that prevents the understanding and signing of informed consent, those with an altered general 


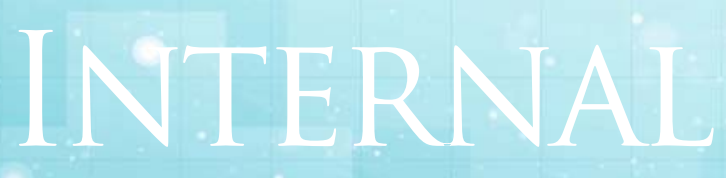

Original Papers

condition or those who, for various reasons, could not return to hospital for scheduled visits (difficulties in mobilization, geographical distance, the fact of belonging to other medical centres) were not included in the study. After obtaining their informed consent, patients were given laboratory parameters and evaluated by ultrasound. All data were obtained from the patient charts and from the previous medical documents in hospital's archive or patient's personal archive.

This study was conducted with the approval of the local Ethics Council. The study was intended to be observational; there were no therapeutic interventions for the purpose of the study. Patients were followed for 6 months, with records created on haemorrhagic events and deaths.

The patients were divided into two groups depending on the presence or absence of antithrombotic treatment. The general characteristics were recorded, then the data were analyzed comparatively between the 2 groups. Microsoft Excel and IBM SPSS Statistics 20 were used for statistical analysis.

\section{Results}

85 patients with a mean age of $63.81 \pm 11.81$ years old, 49 men and 36 women, were enrolled. Patients were included in the study regardless of the cirrhosis aetiology. The average duration from the diagnosis of cirrhosis was 3.9 years, with 18 years the longest duration, at the opposite end of the scale being patients diagnosed at the time of enrolment. The aetiology of cirrhosis was mainly associated with hepatitis viruses ( 5 patients with virus $B, 2$ with association of viruses $B$ and $D, 21$ with virus $C$ ) and alcohol consumption ${ }^{(28)}$. Otherwise, it was secondary to a cardiac disease (7), or a mixed pathology (alcoholic and cardiac - 8), in 2 cases induced by amiodarone and cryptogenetic for the remaining cases (Figure 1 ).

General characteristics of patients, the averages and standard deviations of clinical, laboratory, and ultrasound parameters at the time of enrolment were included in Table 1.

Patients were divided into two groups, one with patients treated with antithrombotic drugs and the other without antithrombotic treatment. Antithrombotic treatment was initiated in the context of associated cardiac pathology (ischemic heart disease, primary or secondary prophylaxis of stroke, myocardial infarction) and consisted of aspirin in cardiac dose, clopidogrel or acenocoumarol.

The mortality rates of the two groups were comparable, $11.54 \%$ untreated and $12.12 \%$ treated, respectively. The decompensation rate of untreated patients was higher than that of patients treated with antithrombotic 

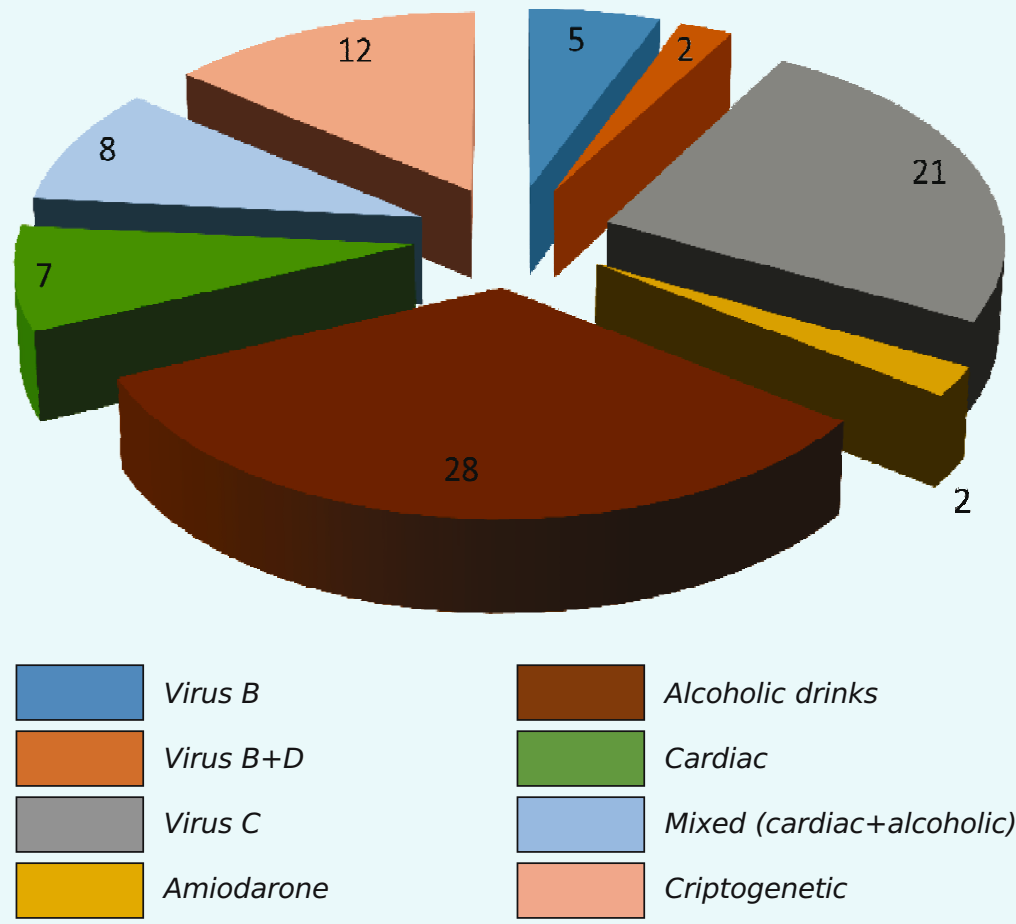

Figure 1. Distribution of patients according to the etiology of cirrhosis

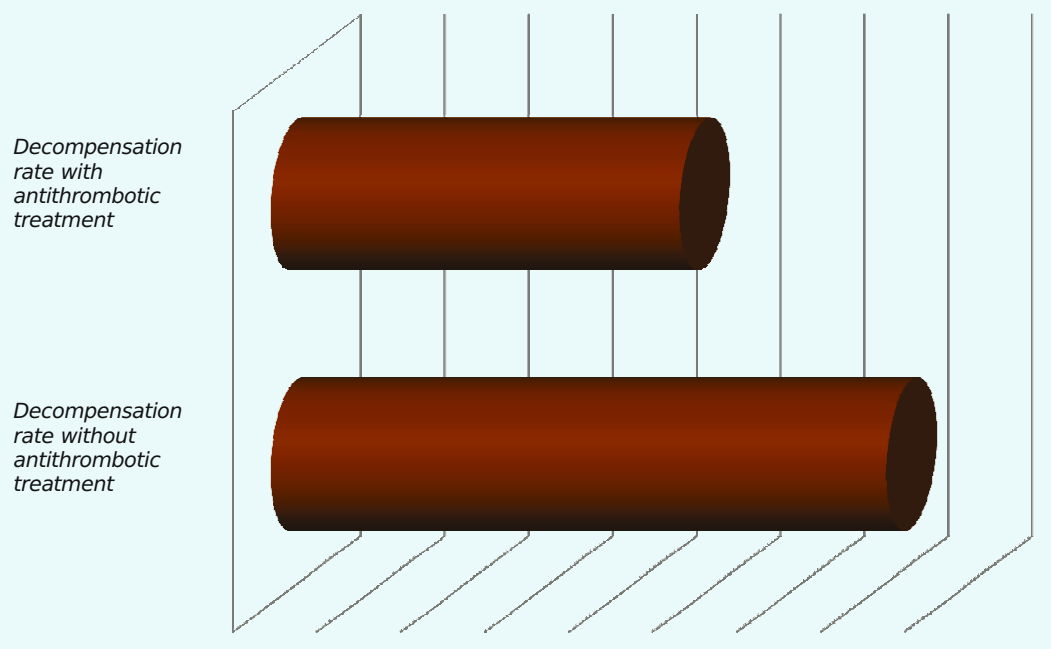

$0.00 \% 5.00 \% 10.00 \% 15.00 \% 20.00 \% 25.00 \% 30.00 \% 35.00 \% 40.00 \%$

Figure 2. Difference in decompensation rates depending on antithrombotic treatment 


\section{INTERNAL}

\section{Original Papers}

drugs (36.54 \% vs. $24.24 \%$ ) (Figure 2). Using the Crosstab function in the SPSS application menu, statistically significant differences were obtained between the evolution of patients treated and untreated with antithrombotic drugs. The Pearson ChiSquare test showed for $p=0.038(<0.05)$ that the percentage of patients who had UGB (upper gastrointestinal bleeding) differed significantly between treated $(0 \%)$ and untreated $(11.8 \%)$ patients, none of the patients treated with antithrombotic presenting UGB.

\section{Discussion}

The two most common aetiologies of this group were the $C$ virus and the consumption of alcoholic beverages, as described in the general population, which is an argument for the representativeness of the group. The two groups were balanced in terms of age, with an average of $66.91 \pm 10.67$ years old for those treated with $A D$ (antithrombotic drugs) and $61.85 \pm 12.18$ years old for those not treated $(p=0.05)$, respectively.

There were no statistically significant differences between the portal vein (PV) values at enrollment between the two groups. $13.74 \pm 1.54 \mathrm{~mm}$ AD, $14.40 \pm 1.72 \mathrm{~mm}$ untreated ( $p=0.25$ ), which is an indirect marker for quantifying portal hypertension $(\mathrm{PHT})$. Likewise, there were no such differences between the average values of total serum proteins, a laboratory parameter that explores the liver function $6.84 \pm 0.85$ $\mathrm{g} / \mathrm{dL} A D$, respectively $6.91 \pm 0.85 \mathrm{~g} / \mathrm{dL}$ untreated ( $p=0.75$ ), which reflects the severity of the disease balanced between the two groups.

The prognosis of untreated versus treated patients at enrolment was also estimated using the MELD (Model for End Stage Liver Disease) score, $17.5 \pm 6.66$ compared to $15.6 \pm 4.42(p=0.19)$, which was confirmed in the evolution of patients, although it did not register a statistically significant difference, the decompensation rate being directly proportional to the MELD value.

Although the mortality rates of the two groups were comparable, the causes of death were different. Among those treated with $A D$, the main cause of death was decompensated heart failure $37.5 \%$, while the death of those untreated was caused mainly by UGBvariceal haemorrhage $40 \%$, a common complication of cirrhosis.

It is important to remember that those not treated with $A D$ had as their main cause of mortality a major haemorrhagic event, the actual dreaded adverse reaction of these drugs especially in these patients, while none of those treated had UGB, which confirms the premises of this study. Mortality among those treated with $A D$ is influenced by cardiovascular comorbidities. 


\begin{tabular}{|c|c|}
\hline Characteristic & $\begin{array}{l}\text { Average } \\
\text { and standard } \\
\text { deviation }\end{array}$ \\
\hline Age & $63.81 \pm 11.81$ \\
\hline Weight (kg) & $81.33 \pm 18$ \\
\hline Height $(\mathrm{cm})$ & $165.40 \pm 11.13$ \\
\hline Body Mass Index (BMI) & $29.75 \pm 6.04$ \\
\hline Diagnosis from LC (years) & $3.9 \pm 6$ \\
\hline $\begin{array}{l}\text { Systolic Blood Pressure - } \\
\text { SBP }(\mathrm{mmHg})\end{array}$ & $124.52 \pm 15.67$ \\
\hline $\begin{array}{l}\text { Diastolic Blood Pressure - } \\
\text { DBP }(\mathrm{mmHg})\end{array}$ & $67.82 \pm 10.56$ \\
\hline $\begin{array}{l}\text { Ventricular rate - VR } \\
\text { (bpm) }\end{array}$ & $80 \pm 13$ \\
\hline LSH (mm) & $81.57 \pm 16.2$ \\
\hline LDH (mm) & $168.13 \pm 20.89$ \\
\hline $\mathrm{PV}(\mathrm{mm})$ & $14.15 \pm 1.68$ \\
\hline $\begin{array}{l}\text { Inferior vena cava - IVC } \\
(\mathrm{mm})\end{array}$ & $20.56 \pm 6.41$ \\
\hline Spleen $(\mathrm{mm})$ & $143.33 \pm 23.2$ \\
\hline $\begin{array}{l}\text { Sedimentation rate - SR } \\
(\mathrm{mm})\end{array}$ & $7.93 \pm 2.49$ \\
\hline Creatinine (mg/dL) & $1.11 \pm 0.69$ \\
\hline TB $(\mathrm{mg} / \mathrm{dL})$ & $2.16 \pm 2.68$ \\
\hline INR & $1.62 \pm 0.53$ \\
\hline Sodium (mmol/L) & $137.99 \pm 4.19$ \\
\hline MELD & $16.67 \pm 5.82$ \\
\hline Haemoglobin (g/dL) & $10.98 \pm 2.82$ \\
\hline Platelets $(1000 / \mu \mathrm{L})$ & $169.75 \pm 83.72$ \\
\hline 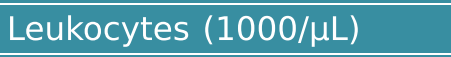 & $6.38 \pm 3.16$ \\
\hline $\begin{array}{l}\text { Mean corpuscular volume } \\
\text { - MCV (fL) }\end{array}$ & $91.76 \pm 12.30$ \\
\hline Total cholesterol (mg/dL) & $132.98 \pm 44.01$ \\
\hline AST (U/L) & $85.65 \pm 192.45$ \\
\hline ALT (U/L) & $56.39 \pm 216.94$ \\
\hline Glucose (mg/dL) & $125.91 \pm 57.4$ \\
\hline GGT (U/L) & $181.6 \pm 227.66$ \\
\hline $\begin{array}{l}\text { Total serum protein } \\
\text { (g/dL) }\end{array}$ & $6.87 \pm 0.84$ \\
\hline Albumin\% & $49.22 \pm 6.76$ \\
\hline AFP (ng/mL) & $4.49 \pm 6.43$ \\
\hline Sideremia $(\mu \mathrm{g} / \mathrm{dL})$ & $84.6 \pm 52.5$ \\
\hline$\%$ Prothrombin & $59.24 \pm 16.73$ \\
\hline Quick time (seconds) & $18.16 \pm 5.20$ \\
\hline Serum uric acid (mg/dL) & $6.41 \pm 2.26$ \\
\hline
\end{tabular}

Table 11. Characteristics of patients with SLE and HCV with/without post IS (immunosuppression) HCV reactivation ${ }^{(18)}$

CNS - central nervous system; PH - pulmonary hypertension. 


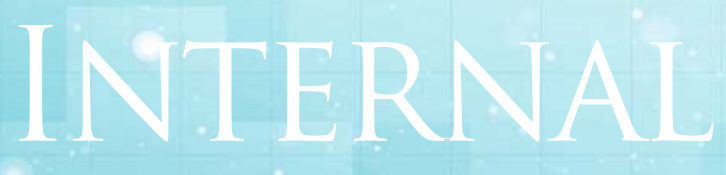

Original Papers

Therefore, it would be interesting to verify whether the administration of this treatment to patients suffering only from cirrhosis would determine the decrease of their mortality, as well. The difference in evolution between the two groups, with more frequent decompensations among those not treated with antithrombotic drugs, may be the result of administering these drugs. Portal vein thrombosis in advanced liver cirrhosis is a marker of disease severity and decompensation, not being the trigger for liver decompensation ${ }^{(6)}$.

In one study, cirrhotic patients had a relative risk of venous thromboembolism 1.7 times higher than the general population ${ }^{-(7)}$. In patients under the age of 45 years this remark is confirmed, but after this age the risk becomes comparable to that of the general population ${ }^{-(7)}$. Thrombotic status in patients with liver cirrhosis has also been associated with the progression of liver fibrosis in addition to the influence of portal or non-portal thrombosis ${ }^{(8.9)}$.

As a pathophysiological substrate, the activation of hepatic stellate cells has been proposed as a means to cause the progression of fibrosis or as a result of local ischemic changes caused by microthrombir, ${ }^{(8,9)}$. Although there is a decrease of prothrombin in cirrhosis, so less thrombin is formed, there is also a simultaneous decrease in antithrombin production. Thrombin forms faster and is inactivated more slowly in patients with cirrhosis. Prolonged thrombin activity may promote liver fibrosis. Hepatic stellate cells, that are responsible for liver fibrosis, increase the number of thrombin receptors (the process of upregulation) in response to liver injury and thus maintain liver damage from cirrhosis ${ }^{(10)}$.

Endothelial dysfunction of the hepatic sinusoids in cirrhosis is a key mediator of the pathogenesis of increased vascular resistance. Mechanisms are involved that lead to a decrease in the production of NM (nitrogen monoxide). Bacterial translocation that activates the cytokine cascade also leads to decreased intrahepatic NM production and stimulates its production in the arterial vascular bed leading to increased blood flow through $\mathrm{PV}^{(11)}$.

The von Willebrand factor does not occur in the intrahepatic vascularization of healthy subjects as opposed to cirrhotic ones, and its circulating levels are much higher in cirrhotic subjects than healthy ones and are directly proportional to the severity of cirrhosis ${ }^{(11)}$. The increase in the inflammatory response with the exacerbation of the disease leads to the accumulation of von Willebrand antigen ( $\mathrm{vW}$ $\mathrm{Ag}$ ) - a marker of endothelial dysfunction in patients with cirrhosis - in liver microcirculation, which amplifies platelet adhesion and aggregation to the endothelium of hepatic sinusoids. The result 


\begin{tabular}{|c|c|c|}
\hline Enrolment characteristic & $\begin{array}{l}\text { Mean and standard } \\
\text { deviation for patients } \\
\text { treated with AD }\end{array}$ & $\begin{array}{l}\text { Mean and standard } \\
\text { deviation for patients } \\
\text { not treated with AD }\end{array}$ \\
\hline Age & $66.91 \pm 10.67$ & $61.85 \pm 12.18$ \\
\hline Weight (kg) & $84.64 \pm 21.21$ & $79.22 \pm 15.45$ \\
\hline BMI $(\mathrm{kg} / \mathrm{m} 2)$ & $29.87 \pm 6.51$ & $29.68 \pm 5.79$ \\
\hline Duration LC (years) & $1.91 \pm 4.76$ & $5.17 \pm 6.40$ \\
\hline $\begin{array}{l}\text { Systolic Blood Pressure - SBP } \\
(\mathrm{mmHg})\end{array}$ & $122.27 \pm 20.40$ & $125.96 \pm 11.72$ \\
\hline $\begin{array}{l}\text { Diastolic Blood Pressure - DBP } \\
(\mathrm{mmHg})\end{array}$ & $67.57 \pm 12.5$ & $67.98 \pm 9.25$ \\
\hline Ventricular rate - VR (bpm) & $80 \pm 16.00$ & $80.57 \pm 12.67$ \\
\hline $\mathrm{LSH}(\mathrm{mm})$ & $83.79 \pm 17.07$ & $80.05 \pm 15.57$ \\
\hline $\mathrm{LSH}(\mathrm{mm})$ & $34.45 \pm 6.86$ & $34.18 \pm 5.91$ \\
\hline $\mathrm{LDH}(\mathrm{mm})$ & $170.79 \pm 18.30$ & $166.47 \pm 22.39$ \\
\hline $\mathrm{PV}(\mathrm{mm})$ & $13.74 \pm 1.54$ & $14.40 \pm 1.72$ \\
\hline Inferior vena cava - IVC (mm) & $24.24 \pm 6.41$ & $18.66 \pm 4.49$ \\
\hline $\begin{array}{l}\text { Longitudinal axis spleen } \\
(\mathrm{mm})\end{array}$ & $133.72 \pm 15.31$ & $149.41 \pm 25.33$ \\
\hline Sedimentation rate - SR (mm) & $6.99 \pm 1.83$ & $8.46 \pm 2.67$ \\
\hline Creatinine (mg/dL) & $1.09 \pm 0.38$ & $1.13 \pm 0.84$ \\
\hline $\mathrm{TB}(\mathrm{mg} / \mathrm{dL})$ & $1.36 \pm 0.94$ & $2.65 \pm 3.25$ \\
\hline INR & $1.70 \pm 0.64$ & $1.40 \pm 0.33$ \\
\hline Sodium (mmol/L) & $138.64 \pm 2.82$ & $137.52 \pm 4.93$ \\
\hline MELD & $15.6 \pm 4.42$ & $17.5 \pm 6.66$ \\
\hline Haemoglobin (g/dL) & $11.84 \pm 2.95$ & $10.41 \pm 2.61$ \\
\hline Platelets $(1000 / \mu \mathrm{L})$ & $204.7 \pm 73.90$ & $147.08 \pm 82.5$ \\
\hline 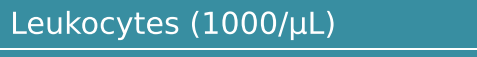 & $6.91 \pm 3.07$ & $6.04 \pm 3.19$ \\
\hline $\begin{array}{l}\text { Mean corpuscular volume - } \\
\text { MCV (fL) }\end{array}$ & $89.45 \pm 7.82$ & $92.29 \pm 12.20$ \\
\hline Total cholesterol (mg/dL) & $128.76 \pm 38.59$ & $137.19 \pm 49.17$ \\
\hline AST (U/L) & $48.01 \pm 93.97$ & $115.76 \pm 241.48$ \\
\hline ALT (U/L) & $27.96 \pm 45.64$ & $74.75 \pm 275.49$ \\
\hline Glucose (mg/dL) & $111.51 \pm 28.38$ & $134.44 \pm 67.95$ \\
\hline GGT (U/L) & $113.76 \pm 95.03$ & $236.25 \pm 284.02$ \\
\hline Total serum protein (g/dL) & $6.84 \pm 0.85$ & $6.91 \pm 0.85$ \\
\hline Albumin\% & $51.34 \pm 6.85$ & $46.96 \pm 5.97$ \\
\hline AFP $(n g / m L)$ & $4.23 \pm 6.07$ & $4.74 \pm 6.88$ \\
\hline Sideremia $(\mu \mathrm{g} / \mathrm{dL})$ & $86.35 \pm 53.62$ & $81.59 \pm 52.00$ \\
\hline$\%$ Prothrombin & $55.94 \pm 19.06$ & $61.44 \pm 14.79$ \\
\hline Quick time (seconds) & $19.32 \pm 6.90$ & $17.39 \pm 3.55$ \\
\hline Serum uric acid (mg/dL) & $6.33 \pm 1.75$ & $6.56 \pm 3.31$ \\
\hline
\end{tabular}

Table 11. Characteristics of patients with SLE and HCV with/without post IS (immunosuppression) HCV reactivation ${ }^{(18)}$

CNS - central nervous system; PH - pulmonary hypertension. 


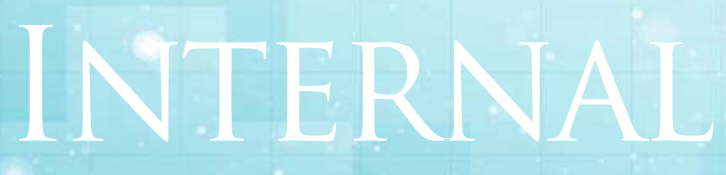

Original Papers

is intrahepatic microthrombi, the progressive occlusion of portal microcirculation and the increase of portal tension ${ }^{(11)}$.

Cytokines released by bacterial translocation such as TNF- $\alpha$, IL-1 may potentiate the prothrombotic status produced by wW Ag in the liver through the process of downregulation of hepatic protein C synthesis. The von Willebrand factor is cleaved by the ADAMTS13 protease, which is mainly synthesized in the liver. In cirrhosis, TNF- $\alpha$, IL- 4 and IL-8 decrease ADAMTS13 synthesis in hepatic stellate and endothelial cells ${ }^{(11)}$. Practically, administering antithrombotic drugs to these patients acted on one of the mechanisms of disease progression, which may explain why the rate of decompensation decreased.

Analyzing the pathophysiology of cirrhosis, Kalambokis et al. ${ }^{(11)}$ even propose the administration of anti-inflammatory and antithrombotic drugs for modelling portal tension in cirrhosis. There is evidence to suggest that anticoagulation has additional benefits to PVT resolution. In a randomized study $^{(12)}$, patients with liver cirrhosis (LC) without PVT who received enoxaparin had lower decompensation rates than untreated ones $^{(12)}$. The same study also found that bacterial DNAs 16 and IL- 6 showed low levels in the enoxaparin-treated group, suggesting that decreased bacterial translocation and inflammation could underlie the positive effect of enoxaparin. Studies in mice support this assumption, with experimentally induced cirrhosis being influenced by a decrease in portal pressure through the administration of enoxaparin. There has been a decrease in intrahepatic resistance by reducing the activation of stellate cells, decreasing the formation of microthrombi and fibrosis in the liver $^{(13)}$. Studies on the prophylaxis of venous thrombolysis in cirrhotic patients have shown that anticoagulation does not increase the risk of bleeding(3). An example is the retrospective study of 235 patients with LC (355 hospitalizations over three years) who received thromboprophylaxis during hospitalization and who showed that gastrointestinal bleeding and mortality rates are not high in these patients ${ }^{(14)}$.

The results of a meta-analysis on anticoagulation of patients with cirrhosis and atrial fibrillation show that this, in addition to decreasing the risk of stroke, does not increase the risk of bleeding compared to non-anticoagulated cirrhotic patients ${ }^{(15)}$.

Another meta-analysis that evaluated the effects of anticoagulation, this time in 257 patients with cirrhosis and PVT, did not reveal differences between minor and major bleeding rates between treated and untreated patients, with the bleeding rate being $11 \%$ in both groups. In four of these studies, the rate of variceal hemorrhage was lower in patients treated with anticoagulants 
than in those untreated ( $2 \%$ versus $12 \%)^{(13)}$. However, most data on anticoagulation in cirrhosis are provided by patients with compensated cirrhosis, where the risk of bleeding does not appear to be increased(6), and there is currently no recommendation of routine prophylactic administration of LMWG in cirrhosis ${ }^{(1)}$.

Although few, studies on the administration of DOAC (Direct Oral Anticoagulants) in cirrhosis show that, in addition to the positive effects on thrombotic changes - PVT or thromboembolism, DOAC appear to have antifibrotic effects by inhibiting thrombin and activated factor $X(X a)^{(10)}$.

Factor Xa promotes contractility and activation of stellate cells. Early inhibition of coagulation using factor Xa inhibitor significantly reduces thioacetamide-induced liver fibrosis and may be a viable treatment for LC patients. ${ }^{(16)}$ However, studies and evidence on the action of DOAC in cirrhosis are insufficient and there are currently no recommendations for use in cirrhotic patients ${ }^{(1)}$. Coumarin administration is problematic in patients with cirrhosis, the biggest concern being the INR (International Normalized Ratio) target in a patient with an already high value. Thromboelastography or thrombin generation tests are indicated as follow-up methods ${ }^{-1,17)}$.

Thrombin Generation Assay (TGA) is a test that measures the amount of thrombin produced in response to the action of the tissue factor in plasma, which uses an automatic calibrated thrombogram. The resulting thrombogram was validated as a good indicator of thrombotic and hemorrhagic conditions $^{(18)}$. The pharmacokinetics and pharmacodynamics of clopidogrel are unaltered in patients with Child $A$ and $B$ cirrhosis, but are not recommended in patients with advanced cirrhosis ${ }^{417)}$.
Administration of aspirin to patients without significant esophageal varices does not appear to pose a risk after coronary stenting $^{-(17)}$ and, moreover, aspirin and enoxaparin may improve liver fibrosis ${ }^{(19)}$.

There are no recommendations in the atrial fibrillation guidelines regarding anticoagulation of patients with cirrhosis. However, liver disease is included in the HAS-BLED score ${ }^{(20)}$. However, what the current guidelines recommend is the treatment of symptomatic PVT in patients with cirrhosis with LMWG or warfarin for at least 6 months ${ }^{(1)}$. Before antithrombotic treatment initiation in a patient with cirrhosis, one should check for the presence of esophageal varices and perform the prophylaxis of varicose hemorrhage either by endoscopic treatment (bandaging, ligation) or by administration of beta-blockers ${ }^{(1,21)}$. Patients with cirrhosis and thromboembolic risk factors should not be omitted from receiving prophylactic treatment, but no recommendations are given for the type of drug or dose, studies being needed in this regard ${ }^{(3,-17)}$.

\section{Conclusions}

Patients with liver cirrhosis who receive antithrombotic treatment have a better prognosis than those not treated with these drugs, in the absence of major bleeding complications.

Studies on a larger number of patients are needed to validate these observations so that this new perspective determine changes in guidelines and current practice

Thanks to doctor Eugenia Panaitescu, Head of Medical Informatics and Biostatistics at University of Medicine and Pharmacy "Carol Davila", Bucharest for the help offered in the statistical processing of the results obtained. 


\section{INTERNAL}

\section{Original Papers}

\section{References}

1. Flores B, Trivedi HD, Robson SC, Bonder $A$. Hemostasis, bleeding and thrombosis in liver disease. Journal of translational science. 2017;3(3).

2. Buresi M, Hull R, Coffin CS. Venous thromboembolism in cirrhosis: a review of the literature. Canadian Journal of Gastroenterology and Hepatology. 2012;26(12):9058.

3. Dhar A, Mullish BH, Thursz MR. Anticoagulation in chronic liver disease. Journal of hepatology. 2017;66(6):131326.

4. Stine JG, Intagliata NM, Shah NL, Lisman T, Violi $F$, Caldwell SH, et al. Clinical Cirrhosis Dilemmas: Survey of Practice from the 7th International Coagulation in Liver Disease Conference. Digestive Diseases and Sciences. 2019;16.

5. Villa and E, De Maria N. Anticoagulation in cirrhosis. Liver international. 2012;32(6):8789.

6. Rank KM, Lake J. COn: anticoagulation for Portal vein Thrombosis in advanced Cirrhosis. Clinical liver disease. 2018;12(3):80

7. Søgaard $K K$, Horváth-Puhó $E$, Grønbæk $H$, Jepsen $P$, Vilstrup $H$, Sørensen HT. Risk of venous thromboembolism in patients with liver disease: a nationwide populationbased casecontrol study. The American journal of gastroenterology. 2009;104(1):96.

8. Senzolo M, Sartori MT, Lisman T. Should we give thromboprophylaxis to patients with liver cirrhosis and coagulopathy? HPB. 2009;11(6):45964.

9. Aggarwal A, Puri K, Liangpunsakul S. Deep vein thrombosis and pulmonary embolism in cirrhotic patients: systematic review. World journal of gastroenterology: WJG. 2014;20(19):5737.

10. Weinberg EM, Palecki J, Reddy KR. Direct-acting oral anticoagulants (DOACS) in cirrhosis and cirrhosisassociated portal vein thrombosis. In Thieme Medical Publishers; 2019. p. 195208.

11. Kalambokis GN, Baltayiannis G, Christodoulou D. von Willebrand factor antigen as a therapeutic target of portal hypertension in cirrhosis. World journal of gastroenterology. 2016;22(19):4786.
12. Villa E, Cammà C, Marietta $M$, Luongo $M$, Critelli $R$, Colopi $S$, et al. Enoxaparin prevents portal vein thrombosis and liver decompensation in patients with advanced cirrhosis. Gastroenterology. 2012;143(5): 125360.

13. To UK, Garcia-Tsao G. PrO: Patients With advanced Cirrhosis and Portal vein Thrombosis should receive anticoagulation. Clinical liver disease. 2018;12(3):74.

14. Intagliata NM, Henry ZH, Shah N, Lisman T, Caldwell $\mathrm{SH}$, Northup PG. Prophylactic anticoagulation for venous thromboembolism in hospitalized cirrhosis patients is not associated with high rates of gastrointestinal bleeding. Liver International. 2014;34(1):2632.

15. Chokesuwattanaskul R, Thongprayoon C, Bathini T, Torres-Ortiz A, O'Corragain OA, Watthanasuntorn $K$, et al. Efficacy and safety of anticoagulation for atrial fibrillation in patients with cirrhosis: a systematic review and metaanalysis. Digestive and Liver Disease. 2019;51(4):48995.

16. Dhar A, Sadiq F, Anstee QM, Levene AP, Goldin RD, Thursz MR. Thrombin and factor Xa link the coagulation system with liver fibrosis. BMC gastroenterology. 2018;18(1):60.

17. Lisman T, Kamphuisen PW, Northup PG, Porte RJ. Established and new-generation antithrombotic drugs in patients with cirrhosis Possibilities and caveats. Journal of hepatology. 2013;59(2):35866.

18. Youngwon N, Kim J-E, Lim HS, Han K-S, Kim HK. Coagulation proteins influencing global coagulation assays in cirrhosis: hypercoagulability in cirrhosis assessed by thrombomodulin-induced thrombin generation assay. BioMed research international. 2013;2013.

19. Li C-J, Yang Z-H, Shi X-L, Liu D-L. Effects of aspirin and enoxaparin in a rat model of liver fibrosis. World journal of gastroenterology. 2017;23(35):6412.

20. Gallagher $C$, Sanders $P$, Wong $C X$. Anticoagulation for Atrial Fibrillation in Cirrhosis of the Liver: Are Low-Dose Non-Vitamin K Oral Anticoagulants a Reasonable Alternative to Warfarin? 2019;

21. EASL E. EASO. Clinical Practice Guidelines for the Management of Non-Alcoholic Fatty Liver Disease, Obes Facts. 2016;9:6590. 